\title{
Design, synthesis, and evaluation the anti- $\beta$-lactamase activity of new sulphathiazole-derived monobactam compounds
}

\author{
Ahmed A. J. Mahmood', Mohammed A.Al-Iraqi², Faris T. Abachi' \\ 1 Department of Pharmaceutical Chemistry, College of Pharmacy, University of Mosul, Mosul, \\ Iraq. \\ 2 Department of Chemistry, College of Science, University of Mosul, Mosul, Iraq.
}

\begin{abstract}
Received Accepted
30.11.2020 15.12.2020

\section{Abstract}

Objectives: $\beta$-Lactams are the most successful antibiotics for the management of infectious diseases. Unfortunately, the bacterial production of $\beta$-lactamase that hydrolyzes the $\beta$-lactam ring can inactivate these drugs. The use of $\beta$-lactamase inhibitors like (clavulanic acid) in combination with the $\beta$-lactams may reduce this inactivation. The prevalent $\beta$-lactamase phenotype is the TEM-1 of class A released by Gram-positive and Gram-negative bacteria.

Methods: The docking study with TEM-1 $\beta$-lactamase lead to synthesize of new 5 monobactam compounds as the acid chloride derivatives reacted with the Schiff bases compound forming the monobactam ring. The final 5 synthesized compounds were characterized using physical and spectroscopic methods and tested biologically by evaluating their MIC values against 4 strains of $\beta$-lactamase Gram-positive and Gram-negative bacteria. The results were compared with those acquired from using clavulanic acid as a co-inhibiter with amoxicillin against the tested bacteria.

Results: The results revealed that 2 synthesized compounds showed an anti $\beta$ lactamase effect resemble to that of clavulanic acid.

Conclusion: As conclusion; the $\beta$-lactamase active pocket prefers hydrophobic substituents, as the synthesized products with these groups appeared to have the highest affinity.

Keywords: TEM-1 $\beta$-lactamase, sulphathiazole, monobactam, Schiff base, acid chloride, anti- $\beta$-lactamase, antibacterial.$$
\text { تصميم ، تحضير وفعالية نشاط بيتا- لاكتاميز لمشتقات السلفاثايزول كمركبات احادية الاكتام }
$$$$
\text { الأهداف: تعتبر بيتا- لاكتام من انجح المضادات الحيوية في علاج الامر اض المعدية، ولسوء الحظ فأن الأن الانتاج البكتيري للـ }
$$

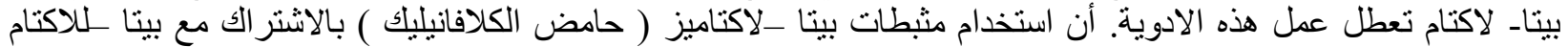
يعمل على يقلل من هذه المقاومة ، وتعتبر خميرة ( تي أي أم -1 ) السائدة من النوع ( أ ) حيث النئ تعمل على تحلل حلقة البيتالاكتنام.

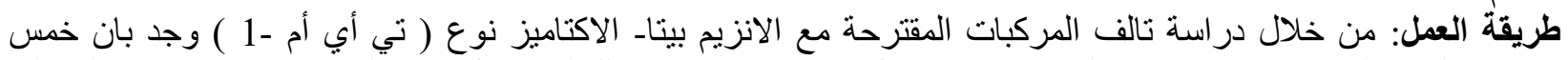

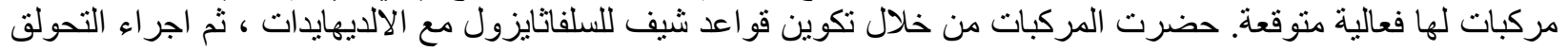




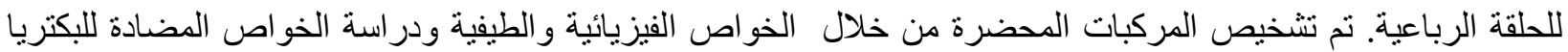

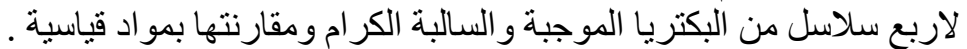

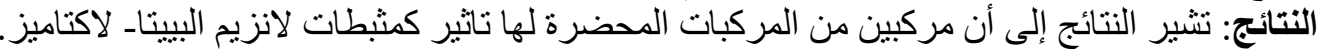

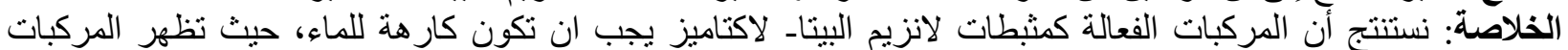

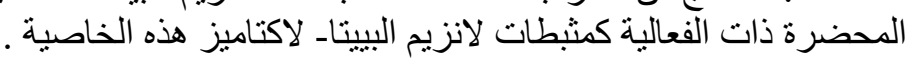

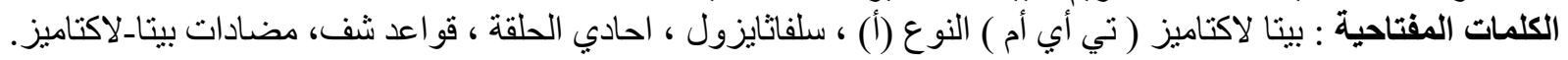

\section{Introduction:}

$1 \begin{aligned} & \text { ntibiotics, particularly the } \beta \text { - } \\ & \text { lactam classes are a } \\ & \text { cornerstone of modern }\end{aligned}$ medicine for fighting the infectious diseases ${ }^{1}$. Their mechanism of action involves inhibition of the synthesis of peptidoglycan (the chief constituent of the bacterial cell wall), thus producing permanent damage and death of the bacteria (bactericidal) ${ }^{1,2}$. The $\beta$-lactam antibiotics group includes four families of antibiotics: the penicillins, cephalosporins, carbapenems and monobactams. All of them are containing a fourmembered $\beta$-lactam ring (azetidin-2one), which is essential for their antibacterial activity ${ }^{1,3}$.

Of the several manifestations of $\beta$-lactams bacterial resistance currently known, the production of beta-lactamases is the most important 2,3 The Ambler system makes use of amino acid sequence to categorize $\beta$ lactamases into four broad classes: A, $\mathrm{B}, \mathrm{C}$, and $\mathrm{D}^{3}$. The $\mathrm{A}, \mathrm{C}$, and $\mathrm{D}$ classes are serine $\beta$-lactamases (SBLs) whereas the class B enzymes are metallo $\beta$-lactamases (MBLs) ${ }^{3,4}$.

The $\beta$-Lactamase inhibitors are affect the capability of the bacteria to inactivate $\beta$-lactam antibiotic, and their administration in combination with $\beta$-lactam antibiotics by co-administration are now the most effective procedures to fight a particular resistance mechanism ${ }^{4,5}$. However, their restricted spectrum of effectiveness, which is restricted to class A enzymes necessitates the search for further broadly effective $\beta$ lactamase inhibitors ${ }^{5}$. Therefore, there is an urgent need to discover and develop new antibiotics or anti $\beta$ lactamases to handle this situation.

Monocyclic $\beta$-lactams are more stable to hydrolysis by $\beta$ lactamases compared to other $\beta$ lactams ${ }^{4}$.The monobactams like Aztreonam belong to a subclass of monocyclic beta-lactam moieties are the only U.S. Food and Drug Administration-approved

monobactam in clinical use ${ }^{5,6}$. This study aims to design, dock (computer calculation), synthesize, and study the 
biological activities of new $\beta$ lactamase inhibitors.

\section{Material and methods:}

All employed chemicals were purchased from commercial sources and their suppliers are Fluka (Switzerland), Alpha (India), Scharlau (Spain), and Merck (Germany). Melting points of the synthesized compound were determined by the Electrochemical CIA 9300 melting point apparatus (UK) by using an open capillary method and they were uncorrected. FTIR spectra were recorded on a PerkinElmer infrared spectrophotometer. 1H NMR and 13C NMR spectra in DMSO-d6 on a Bruker Avance DPX $400 \mathrm{MHz}$ spectrometer using TMS as an internal reference. All the products were synthesized by the method given in the literature and identified by ${ }^{1} \mathrm{H}$ NMR ${ }^{13} \mathrm{C}$ NMR and IR spectra and microanalyses of these compounds were in satisfactory agreement with the structures. The purity of the compounds and the completion of the reactions were monitored by TLC using pre-coated silica gel plate.

\section{Docking Study:}

The Computational Docking Study was carried out using the online platform Mcule by AutoDockVina logarithm (https://mcule.com/ apps/1click-docking/). The structure of the bacterial Penicillin Binding Proteins PBP (1qmf) and $\beta$-lactamases TEM-1 (1pzo) were retrieved from $\mathrm{PDB}^{7}$.

\section{Docking Study on Penicillin Binding Protein (PBP):}

The docking study of the investigated products on PBP (1qmf) was conducted to test the antimicrobial activities of investigated products ${ }^{8}$, and to be compared with reference antibiotics of various activities to validate this approach.

\section{Docking Study on $\beta$-Lactamases TEM-1:}

The docking study of the investigated products on $\beta$-lactamases TEM-1 (1pzo) was conducted to investigates the affinity toward the TEM-1 $\beta$-lactamases to be compared with reference anti $\beta$-lactamases of various activities.

The docking scores of the binding energies due to the interaction between the active ligands (inhibitors) and the enzymes pockets were chosen with the highest score based on geometric shape complementarity ${ }^{9}$. 


\section{Chemical study:}

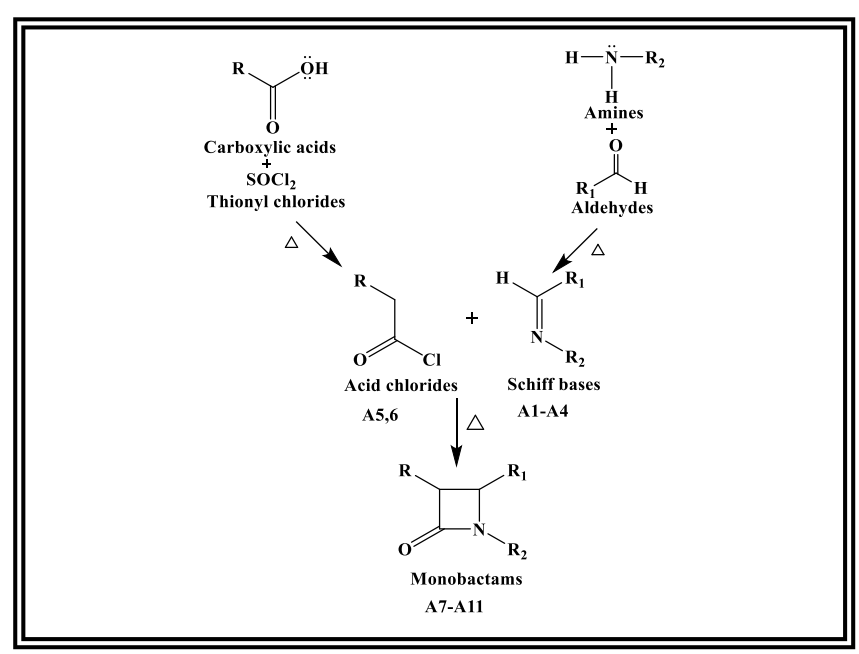

General procedure for the preparation of Schiff base derivatives (A1-A4) ${ }^{10,11}$ :

A (0.004) mole of benzaldehyde derivatives was dissolved by heating in $20 \mathrm{ml}$ absolute ethanol before mixing with (0.004) mole of sulphathiazole which was also dissolved by heating in $20 \mathrm{ml}$ absolute ethanol, then the mixture was refluxed with stirring for $10-15 \mathrm{~h}$ (the proceeding of the reaction was monitored by TLC using 1:1:1 methanol: diethylether : DCM as eluent), after cooling the precipitate was filtered, dried and then washed once with cold ethanol and 3 times with distilled water and dried.

General procedure for the preparation of acid chloride derivatives (A 5 and $\mathrm{A6}$ ) ${ }^{12}$ :

A (3-5 mole) of individual carboxylic acids was dissolved in 10$15 \mathrm{ml}$ of thionyl chloride, the mixture was reflxed for $30 \mathrm{~min}$ in the hood, then the excess of thionyl chloride was distilled under reduced pressure, after cooling the yielded products was taken and used freshly in the next step.

General procedure for the preparation of monobactam derivatives (A7-A11) ${ }^{13}$ :

The corresponding acid chloride (0.0016) mole in $10 \mathrm{ml}$ dichloroethane was added drop by drop to a mixture of a corresponding Schiff base (0.0016) mole with (0.0016) mole pyridine in $30 \mathrm{ml}$ dichloroethane at $0^{\circ} \mathrm{C}$. The resulting mixture was reflexed for $20-25 \mathrm{~h}$ (as 
monitored by TLC using 1:2:2 ethanol: diethyl ether: DCE as eluent). After cooling the solution was washed twice with water $(30 \mathrm{~mL})$, saturated aqueous $\mathrm{NaHCO} 3(30 \mathrm{~mL})$ and finally with saturated solution of $\mathrm{NaCl}(30$ $\mathrm{mL}$ ). The organic layer was removed and dried using anhydrous sodium sulphate. After solvent evaporation, the dry product was washed with cold ethanol.

\section{Antimicrobial Study}

Detection of $\beta$-lactamases in bacterial isolate:

The detection of $\beta$-lactamases in bacterial isolates was done for Gram-positive (Staphylococcus aurous) and 3 Gram-negative (Escherichia coli, Klebsiella pneumonia, and Pseudomonas aeroginosa) pathogenic bacteria isolates using acidimetric method ${ }^{14}$. Were $2 \mathrm{~mL}$ of $0.5 \%(\mathrm{w} / \mathrm{v})$ aqueous phenol red solution was diluted with $16.6 \mathrm{~mL}$ distilled water and $1.2 \mathrm{~g}$ of benzylpenicillin is added. The $\mathrm{pH}$ is adjusted to 8.5 with $1 \mathrm{M} \mathrm{NaOH}$. Then $100 \mu \mathrm{l}$ of resulting violet solution was distributed into tubes and inoculated with several colonies of bacteria from culture to get a dense suspension. A yellow color within 5 min indicates $\beta$ lactamase activity. Positive controls were run in parallel ${ }^{15}$.

\section{Determination of minimum inhibitory concentration (MIC) ${ }^{16}$ :}

A broth microdilution method was used to evaluate the MIC according to the CLSI (CLSI document M7-MIC, Clinical Laboratory Standards Institute). A serial of 10 doubling dilution of the synthesized compounds and standard antibacterial (Amoxiclav (Amoxicillin 2000mg + clavulanic acid 400mg), Amoxicillin,

Cefotaxime, Ceftriaxone, and Ciprofloxacin) was prepared in test tubes with final concentration starting from 2000 $\mu \mathrm{g} / \mathrm{ml}$. A $1 \mathrm{ml}$ of Mueller-Hinton agar was added. Bacterial isolates were diluted and added to the test tubes to give a final concentration $5 \times 10^{5} \mathrm{CFU} / \mathrm{ml}$. The test tubes incubated at $37^{\circ} \mathrm{C}$ for $18 \mathrm{~h}^{17}$. The $(+)$ ve control containing MuellerHinton agar and bacterial isolates only, whereas the (-)ve control containing only Mueller-Hinton agar.

\section{Determination of anti $\beta$-lactamase activities:}

The anti $\beta$-lactamase activity of the synthesized compounds against human pathogenic bacterial isolates was evaluated by measuring the zones of inhibition in the disk diffusion method $^{16}$. Each tested compound was used as co-inhibiter with 1000 or $2000 \mu \mathrm{g}$ of amoxicillin prepared as 


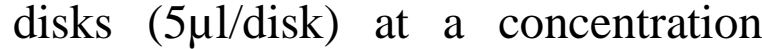
equal or below their MIC, and then placed on Petri dish with MuellerHinton agar medium (previously inoculated with the tested bacterial strains by sterile cotton swabs). After incubation at $37^{\circ} \mathrm{C}$ for $24 \mathrm{~h}$, zones of microbial growth produced around the tested substances were measured and recorded as the diameters of inhibition 18. Disks containing 1000 or $2000 \mu \mathrm{g}$ of amoxicillin $(5 \mu \mathrm{l} /$ disk $)$ was prepared and used as control.

In all the above microbial study DMSO was used as a solvent for the synthesized compounds with a final concentration of less than $2 \%$ in order to ensure that it has no effect on bacterial growth.

\section{Results and discussion:}

Molecular Docking Study for standard inhibitors:

The docking for both clavulanic acid and sulbactam were carried out on both bacterial PBP (1qmf) and $\beta$ lactamases TEM-1 (1pzo). The results are (-6.1) and (-5.1) for clavulanic acid and for sulbactam are (-6.6) and (-6.2) respectively. Docking for monobactam derivatives was carried out on both bacterial PBP (1qmf) and $\beta$-lactamases TEM-1 (1pzo). The chemical structures of the designated substitutions are listed in Table (1), while the results of docking are listed in Table (2).

Table (1): The chemical structures of the designated substitutions.

\begin{tabular}{|c|c|c|c|c|c|}
\hline $\bar{~} \bar{R}$ & Structure & 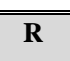 & structure & $\overline{\bar{Z}}$ & structure \\
\hline R1 & & R9 & & $\mathrm{Z1}$ & $\mathrm{Cl}^{-}$ \\
\hline R2 & & R10 & & $\mathrm{Z} 2$ & \\
\hline R3 & & R11 & & Z3 & \\
\hline R4 & & R12 & & Z4 & $\mathrm{CH}_{3}$ \\
\hline R5 & & R13 & & Z5 & $\mathrm{Br}$ \\
\hline R6 & & R14 & & Z6 & \\
\hline
\end{tabular}




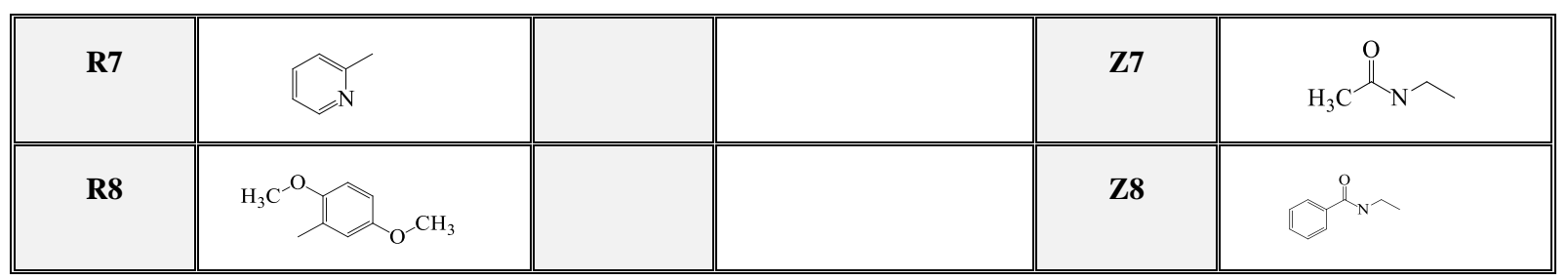

Table (2): Docking Study results for monobactam sulphathiazole derivatives.

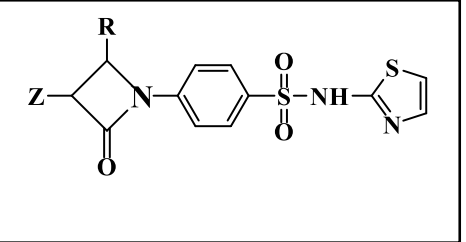

\begin{tabular}{|c|c|c|c|c|c|c|c|c|}
\hline \multirow[t]{2}{*}{ Comp. } & \multicolumn{2}{|c|}{$\begin{array}{l}\text { Docking Scour } \\
\end{array}$} & \multirow[t]{2}{*}{ Comp. } & \multicolumn{2}{|c|}{ Docking Scour } & \multirow[t]{2}{*}{ Comp. } & \multicolumn{2}{|c|}{$\begin{array}{l}\text { Docking Scour } \\
\end{array}$} \\
\hline & PBP & B-Lactm. & & $\overline{P B P}$ & B-Lactm. & & PBP & B-Lactm. \\
\hline R1, Z1 & \begin{tabular}{c|}
-8.8 \\
\end{tabular} & -7.9 & R5, Z7 & 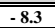 & -6.8 & R10,Z5 & $\overline{-8.6}$ & -8.4 \\
\hline R1, Z2 & -8.3 & -8.2 & $\mathrm{R} 5, \mathrm{Z8}$ & -8.9 & -8.0 & $\mathrm{R} 10, \mathrm{Z6}$ & -8.7 & -8.4 \\
\hline R1, Z3 & -8.6 & -9.4 & R6, Z1 & -9.2 & -8.8 & $\mathrm{R} 10, \mathrm{Z7}$ & -9.1 & -8.6 \\
\hline R1, Z4 & -8.1 & -8.1 & R6, Z2 & -9.3 & -8.5 & R10, Z8 & -9.0 & -8.7 \\
\hline R1, Z5 & -8.3 & -8.3 & R6, Z3 & -9.3 & -8.6 & R11, Z1 & -7.9 & -8.5 \\
\hline R1, Z6 & -7.8 & -8.0 & R6, Z4 & -9.2 & -8.3 & $\mathrm{R} 11, \mathrm{Z} 2$ & -8.3 & -8.0 \\
\hline R1, Z7 & -9.6 & -7.9 & R6,Z5 & -9.2 & -8.2 & $\mathrm{R} 11, \mathrm{Z3}$ & -8.9 & -9.7 \\
\hline R1, Z8 & -9.4 & -8.7 & R6, Z6 & -8.5 & -8.0 & $\mathrm{R} 11, \mathrm{Z4}$ & -8.5 & -8.8 \\
\hline $\mathrm{R} 2, \mathrm{Z1}$ & -8.5 & -8.3 & R6,Z7 & -9.3 & -8.0 & $\mathrm{R} 11, \mathrm{Z5}$ & -8.3 & -8.0 \\
\hline $\mathrm{R} 2, \mathrm{Z} 2$ & -8.8 & -8.3 & R6, Z8 & -9.4 & -7.6 & R11, Z6 & -8.7 & -8.9 \\
\hline $\mathrm{R} 2, \mathrm{Z3}$ & -8.6 & -9.8 & R7, Z1 & -8.1 & -7.7 & R11, Z7 & -8.8 & -8.6 \\
\hline $\mathrm{R} 2, \mathrm{Z4}$ & -8.3 & -8.2 & R7, Z2 & -8.3 & -7.9 & R11, Z8 & -8.3 & -9.5 \\
\hline $\mathrm{R} 2, \mathrm{Z5}$ & -8.3 & -8.4 & $\mathrm{R} 7, \mathrm{Z3}$ & -8.9 & -8.6 & $\mathrm{R} 12, \mathrm{Z1}$ & -8.4 & -8.3 \\
\hline $\mathrm{R} 2, \mathrm{Z6}$ & -8.1 & -7.9 & $\mathbf{R 7}, \mathbf{Z 4}$ & -9.2 & -7.8 & $\mathrm{R} 12, \mathrm{Z2}$ & -8.1 & -7.9 \\
\hline R2, Z7 & -9.2 & -8.4 & R7, Z5 & -8.8 & -7.6 & $\mathrm{R} 12, \mathrm{Z3}$ & -8.3 & -8.3 \\
\hline $\mathrm{R} 2, \mathrm{Z8}$ & -8.9 & -8.1 & R7, Z6 & -8.3 & -7.8 & $\mathrm{R} 12, \mathrm{Z4}$ & -8.9 & -8.0 \\
\hline R3, Z1 & -8.5 & -8.4 & R7, Z7 & -8.6 & -8.3 & $\mathrm{R} 12, \mathrm{Z5}$ & -9.2 & -7.6 \\
\hline $\mathrm{R3}, \mathrm{Z2}$ & -8.5 & -8.4 & R7, Z8 & -8.1 & -8.3 & $\mathrm{R} 12, \mathrm{Z6}$ & -9.3 & -8.0 \\
\hline $\mathrm{R3}, \mathrm{Z3}$ & -9.5 & -8.4 & $\mathrm{R8}, \mathrm{Z1}$ & $\begin{array}{l}-8.3 \\
\end{array}$ & -7.7 & $\mathrm{R} 12, \mathrm{Z7}$ & -9.3 & \begin{tabular}{|l|}
-8.1 \\
\end{tabular} \\
\hline $\mathrm{R3}, \mathrm{Z4}$ & -9.1 & -8.3 & $\mathrm{R8}, \mathrm{Z2}$ & -7.8 & -7.6 & $\mathrm{R} 12, \mathrm{ZB}$ & -9.2 & -9.7 \\
\hline $\mathrm{R3}, \mathrm{Z5}$ & -8.0 & -8.0 & $\mathrm{R8}, \mathrm{Z3}$ & -9.6 & -8.4 & $\mathrm{R} 13, \mathrm{Z1}$ & -9.2 & -8.6 \\
\hline $\mathrm{R3}, \mathrm{Z6}$ & -8.0 & -8.0 & R8, Z4 & -9.4 & -7.9 & $\mathrm{R} 13, \mathrm{Z2}$ & -8.5 & -8.0 \\
\hline $\mathrm{R3}, \mathrm{Z7}$ & -8.8 & $\begin{array}{l}-7.9 \\
\end{array}$ & $\mathrm{R8}, \mathrm{Z5}$ & -8.5 & -7.7 & $\mathrm{R} 13, \mathrm{Z3}$ & -9.3 & -8.7 \\
\hline $\mathrm{R3}, \mathrm{Z8}$ & -8.6 & -8.8 & R8, Z6 & -8.8 & -7.3 & $\mathrm{R} 13, \mathrm{Z4}$ & -9.4 & -8.9 \\
\hline $\mathrm{R4}, \mathrm{Z1}$ & -8.6 & -8.2 & $\mathrm{R8}, \mathrm{Z7}$ & $\begin{array}{l}-8.6 \\
\end{array}$ & $\begin{array}{l}-8.0 \\
\end{array}$ & $\mathrm{R} 13, \mathrm{Z5}$ & -8.8 & $\begin{array}{l}-8.6 \\
\end{array}$ \\
\hline $\mathrm{R4}, \mathrm{Z2}$ & -8.7 & -8.3 & R8, Z8 & -8.3 & -7.7 & $\mathrm{R} 13, \mathrm{Z6}$ & -8.3 & -8.6 \\
\hline R4, Z3 & -9.1 & -8.0 & R9,Z1 & -8.3 & -8.5 & R13,Z7 & -8.6 & -8.4 \\
\hline R4,Z4 & -9.0 & -8.2 & R9,Z2 & -8.1 & -7.9 & $\mathrm{R} 13, \mathrm{ZB}$ & -8.1 & -8.2 \\
\hline $\mathrm{R4}, \mathrm{Z5}$ & -7.9 & $\begin{array}{l}-8.3 \\
\end{array}$ & R9,Z3 & -9.2 & -8.4 & $\mathrm{R} 14, \mathrm{Z1}$ & -9.1 & \begin{tabular}{|l|}
-8.1 \\
\end{tabular} \\
\hline R4, Z6 & -8.3 & -7.6 & R9, Z4 & $\begin{array}{l}-8.9 \\
\end{array}$ & -7.9 & $\mathrm{R} 14, \mathrm{Z2}$ & -9.0 & -8.0 \\
\hline R4, Z7 & -8.9 & -7.4 & R9,Z5 & -8.5 & -7.6 & $\mathrm{R} 14, \mathrm{Z3}$ & -7.9 & \begin{tabular}{ll|}
-8.1 \\
\end{tabular} \\
\hline R4, Z8 & -8.5 & -7.7 & R9,Z6 & -8.5 & -7.7 & R14, Z4 & -8.3 & -8.0 \\
\hline R5,Z1 & -8.3 & -7.1 & R9,Z7 & -9.5 & -8.2 & $\mathrm{R} 14, \mathrm{Zs}$ & -8.9 & -7.5 \\
\hline $\mathrm{R5}, \mathrm{Z2}$ & -8.7 & -7.5 & R9, Z8 & \begin{tabular}{|l|}
-9.1 \\
\end{tabular} & $\begin{array}{l}-8.7 \\
\end{array}$ & $\mathrm{R} 14, \mathrm{Z6}$ & -8.5 & -7.7 \\
\hline $\mathrm{R5}, \mathrm{Z3}$ & -8.8 & $\begin{array}{l}-7.6 \\
\end{array}$ & $\mathrm{R} 10, \mathrm{Z1}$ & $\begin{array}{l}-8.0 \\
\end{array}$ & -8.3 & $\mathrm{R} 14, \mathrm{Z7}$ & -9.5 & $\begin{array}{l}-7.9 \\
\end{array}$ \\
\hline $\mathrm{R5}, \mathrm{Z4}$ & -8.3 & -7.5 & $\mathrm{R} 10, \mathrm{Z} 2$ & -8.0 & -8.6 & $\mathrm{R} 14, \mathrm{ZB}$ & -9.1 & \begin{tabular}{|l|}
-8.0 \\
\end{tabular} \\
\hline R5, Z5 & -8.4 & -7.5 & $\mathrm{R} 10, \mathrm{Z3}$ & -8.8 & -8.3 & & & \\
\hline $\mathrm{R} 5, \mathrm{Z6} 6$ & -8.1 & -7.4 & $\mathrm{R} 10, \mathrm{Z4}$ & -8.6 & -8.5 & & & \\
\hline
\end{tabular}

The docking results showed that as the hydrophobicity increases in the tested compounds the score will decrease. The compounds bound variably to the region located between H10, H11 and H12 helices of TEM-1, indicating that the pocket is mostly hydrophobic in nature ${ }^{19}$, and the residue participated in the binding with our compounds were almost the same as those combined with the standard inhibitors (clavulanic acid and sulbactam).

\section{Chemical results:}

\section{Preparation of Schiff base derivatives (A1-A4):}


This reaction was occurred through nucleophilic addition mechanism. The unshared pair of electron of the amino group attacks the electron seeking carbon of the carbonyl group of the aldehyde to form the aminal intermediate, which losses water molecule to form the imine (Schiff base). The physical properties and the most characteristic peaks of the FTIR spectrum for compounds (A1-A4) are shown in the table (3).
In general these compounds were disposed the absence of the N-H (NH2 group) bond stretching at 3272 $\mathrm{cm}^{-1}$ of the sulphathiazol and appearance of absorption bond at $1580-1590 \mathrm{~cm}^{-1}$ related to the $\mathrm{C}=\mathrm{N}$ bond stretching which indicating the formation of Schiff base. There was an addition of characteristics peaks for each substitution of the aldehydes used.

Table (3): physical properties and the most characteristic peaks $\left(\mathrm{v} \mathrm{cm}^{-1}\right)$ of the FT-IR spectrum for the Schiff base derivatives (A1-A4).

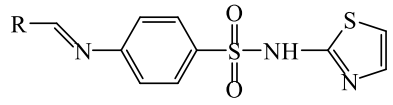

\begin{tabular}{|c|c|c|c|c|c|c|c|c|c|c|c|c|}
\hline Compd & $\mathbf{R}$ & $\mathbf{m} . \mathbf{p}\left({ }^{\circ} \mathbf{C}\right)$ & Yield $\%$ & Color & $\begin{array}{l}\text { Time to } \\
\text { end of the } \\
\text { reaction }\end{array}$ & \begin{tabular}{|c|}
$\mathbf{R}_{\mathrm{f}}$ \\
(Methano \\
11 : \\
Ether 1 : \\
DCM 1) \\
\end{tabular} & N-H & C-H & $\begin{array}{c}\mathrm{C}=\mathrm{N} \\
\text { imine }\end{array}$ & $\mathrm{O}=\mathrm{S}=\mathrm{O}$ & $\begin{array}{c}\mathrm{C}=\mathrm{S} \\
\text { or C-SH }\end{array}$ & C-Cl \\
\hline A1 & R1 & $261-263$ & 93 & White & $10 \mathrm{~h}$ & 0.64 & w 3355 & w 3106 & s 1583 & $\begin{array}{c}\text { s 1332, } \\
1131\end{array}$ & s 1077 & ----- \\
\hline A2 & R2 & $162-164$ & 81 & Off White & $13 \mathrm{~h}$ & 0.63 & w 3349 & w 3118 & s 1583 & $\begin{array}{c}\text { s 1336, } \\
1131\end{array}$ & s 1077 & m 1091 \\
\hline A3 & R11 & $170-172$ & 90 & Yellow & $12 \mathrm{~h}$ & 0.47 & w 3355 & w 3106 & s 1587 & $\begin{array}{c}\text { m 1330, } \\
1130\end{array}$ & s 1080 & ----- \\
\hline A4 & R12 & $260-262$ & 82 & $\begin{array}{c}\text { Dark } \\
\text { yellow }\end{array}$ & $10 \mathrm{~h}$ & 0.42 & w 3348 & m 3105 & s 1584 & $\begin{array}{c}\text { m 1334, } \\
1131\end{array}$ & s 1077 & ----- \\
\hline
\end{tabular}

Preparation of acid chloride derivatives (A5 and A6):
This reaction was occurred via nucleophilic addition-elimination mechanism which involves, firstly 
displacement of chloride from the sulfur by the hydroxyl group to form the acyl chloro-sulfite intermediate. In the second step the chloride ion $\left(\mathrm{Cl}^{-}\right)$ attacks the carbonyl carbon via addition step to form a tetrahedral intermediate, which losses $\mathrm{SO} 2$ and $\mathrm{HCl}$ molecules in the elimination step to form the acid chloride (Table 4).

Table 4: The chemical structures and the colors of the synthesized acid chlorides (A5 and and A6).

\begin{tabular}{|c||c|c||c|c|c||}
\hline $\begin{array}{c}\text { Compd. } \\
\text { No. }\end{array}$ & Chemical structure & Color & $\begin{array}{c}\text { Compd. } \\
\text { No. }\end{array}$ & Chemical structure & Color \\
\hline & & & Gray & Dark red \\
\hline
\end{tabular}

Preparation of monobactam compounds (A7-A11):

This reaction was occurred as the nitrogen of the imine (Schiff base) acts as a nucleophile attacking the acid chloride carbonyl and eliminating the chloride ion as a result. This anion attacks the electron seeking carbonyl carbon via intramolecular nucleophilic addition reaction to form the four membered ring azetidine moiety $(\text { monobactam })^{20}$. The physical properties and the most characteristic peaks of the FT-IR spectrum for these compounds are shown in the Table (5).

Table (5): Physical properties and the most characteristic peaks $\left(\mathrm{v} \mathrm{cm}^{-1}\right)$ of the FT-IR spectrum for the monobactam derivatives (A7-A11)

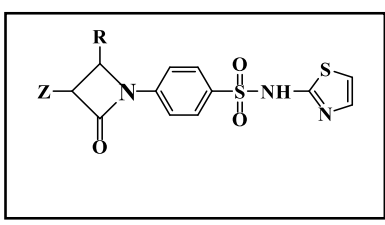

\begin{tabular}{|c|c|c|c|c|c|c|c|c|c|c|c|c|c|c|}
\hline Compd & $\mathbf{Z}, \mathbf{R}$ & $\mathbf{m} . \mathbf{p}\left({ }^{\circ} \mathbf{C}\right)$ & Yield \% & Color & $\begin{array}{l}\text { Time to } \\
\text { end of } \\
\text { the } \\
\text { reaction }\end{array}$ & 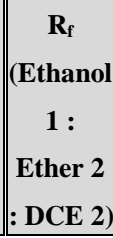 & N-H & \begin{tabular}{|l} 
C-H \\
Stretch.
\end{tabular} & $\begin{array}{c}\mathrm{C}=\mathbf{O} \\
\text { Lactam }\end{array}$ & $\begin{array}{l}\mathrm{C}=\mathbf{N} \\
\text { Imine }\end{array}$ & C-O-C & $\mathbf{O}=\mathbf{S}=\mathbf{O}$ & $\begin{array}{l}\mathrm{C}=\mathrm{S} \text { or } \\
\mathrm{C}-\mathrm{SH}\end{array}$ & C-Cl \\
\hline A7 & Z3, R1 & $\mid 210-212$ & 67 & $\begin{array}{l}\text { Drack- } \\
\text { yellow }\end{array}$ & $25 \mathrm{~h}$ & 0.74 & w 3306 & w 3104 & m 1690 & s 1585 & $\begin{array}{c}\text { m 1231, } \\
1130\end{array}$ & $\begin{array}{c}\text { s 1330, } \\
1136\end{array}$ & s 1077 & m 1085 \\
\hline A8 & $\mathbf{Z 3}, \mathbf{R 2}$ & $\mid 110-112$ & 75 & Yellow & $22 \mathrm{~h}$ & 0.63 & w 3372 & w 3103 & m 1690 & s 1583 & $\mid \begin{array}{c}\text { m 1233, } \\
1128\end{array}$ & $\begin{array}{c}\text { s 1335, } \\
1138\end{array}$ & s 1078 & m 1092 \\
\hline
\end{tabular}




\begin{tabular}{|c|c|c|c|c|c|c|c|c|c|c|c|c|c|c|}
\hline A9 & $\mathrm{Z3}, \mathrm{R} 11$ & $197-200$ & 67 & Yellow & $24 \mathrm{~h}$ & 0.47 & w 3370 & w 3100 & m 1694 & s 1582 & $\begin{array}{c}\text { m 1235 } \\
1133\end{array}$ & $\begin{array}{c}\text { s 1334, } \\
1131\end{array}$ & s 1076 & m 1097 \\
\hline A10 & $\mathrm{Z8}, \mathrm{R} 11$ & $151-154$ & 63 & $\begin{array}{l}\text { Dark- } \\
\text { yellow }\end{array}$ & $24 \mathrm{~h}$ & 0.44 & $\begin{array}{c}\text { w 3339, } \\
\mathbf{3 2 0 0}\end{array}$ & w 3024 & m 1686 & m 1581 & ----- & $\begin{array}{c}\text { s 1330, } \\
1132\end{array}$ & s 1071 & ----- \\
\hline A11 & $\mathrm{Z8}, \mathrm{R} 12$ & 207-210 & 72 & $\begin{array}{l}\text { Dark- } \\
\text { yellow }\end{array}$ & $23 \mathrm{~h}$ & 0.55 & $\begin{array}{c}\text { w 3339, } \\
\mathbf{3 2 3 0}\end{array}$ & w 3059 & m 1691 & m 1588 & ----- & $\begin{array}{c}\text { s 1336, } \\
1131\end{array}$ & s 1078 & ------ \\
\hline
\end{tabular}

The result from the Table (5) indicated that the formation of monobactam ring as its carbonyl group $\mathrm{C}=\mathrm{O}$ appears at $1686-1694 \mathrm{~cm}^{-1}$ which added to the original Schiff bases $\mathrm{C}=\mathrm{N}$ at $1580-1590 \mathrm{~cm}^{-1}$. Also $\mathrm{Z} 8$ acid chloride compound.

${ }^{1} \mathrm{H}-\mathrm{NMR}$ indicate the formation of the four membranes monobactam rings, as the proton NMR shows the appearance of the single proton of the $\mathrm{C} 4$ and $\mathrm{C} 1$ in the compounds A7-11 at 3.90-5.12 ppm and 4.19-5.84 ppm respectively, confirming the reaction of the acid chloride with the Schiff base derivatives forming the ring the appearance of the $\mathrm{C}-\mathrm{O}-\mathrm{C}$ at 1231$1235 \mathrm{~cm}^{-1}$ and the $\mathrm{C}-\mathrm{Cl}$ at 1085-1097 $\mathrm{cm}^{-1}$ for $\mathrm{Z} 3$ acid chloride compound, in addition to the appearance of $\mathrm{N}-\mathrm{H}$ at 3200-3230 $\mathrm{cm}^{-1}$ for (Table 6).

While in the ${ }^{13} \mathrm{C}$-NMR and for compounds A7-11 the appearance of the carbonyl $\mathrm{C} 2$ at $162.98-166.61$ ppm, and the appearance of $\mathrm{C} 1$ and $\mathrm{C} 4$ at 59.06-74.16 ppm and 57.7960.77 ppm respectively also confirm the formation of the monobactam ring (Table 6).

Table 6: The chemical structures synthesized monobactam compounds.

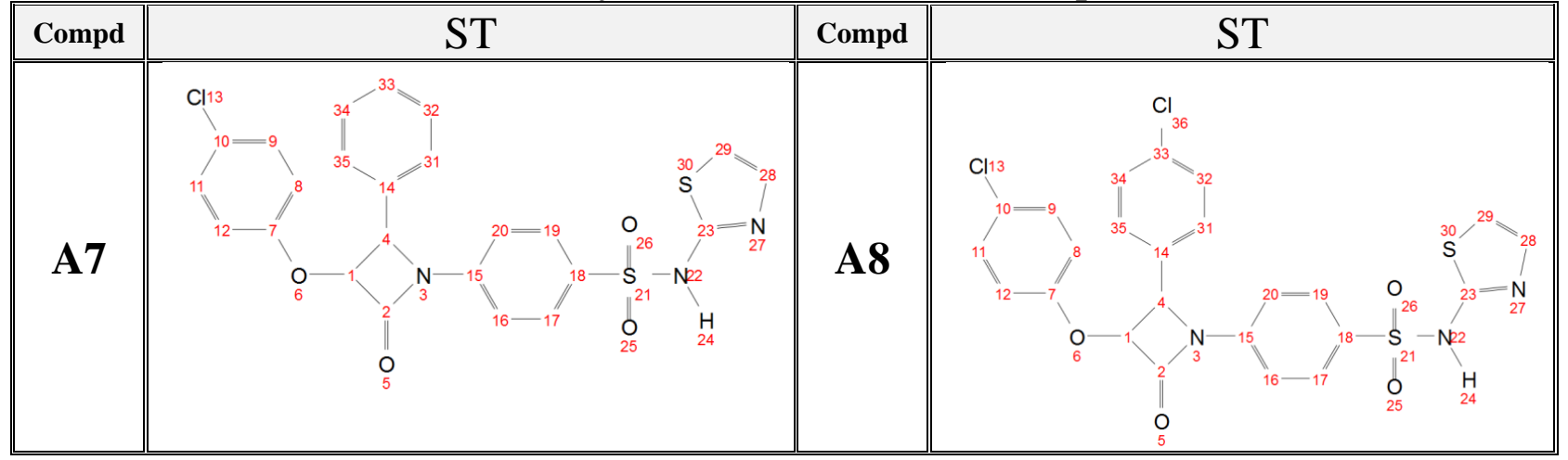




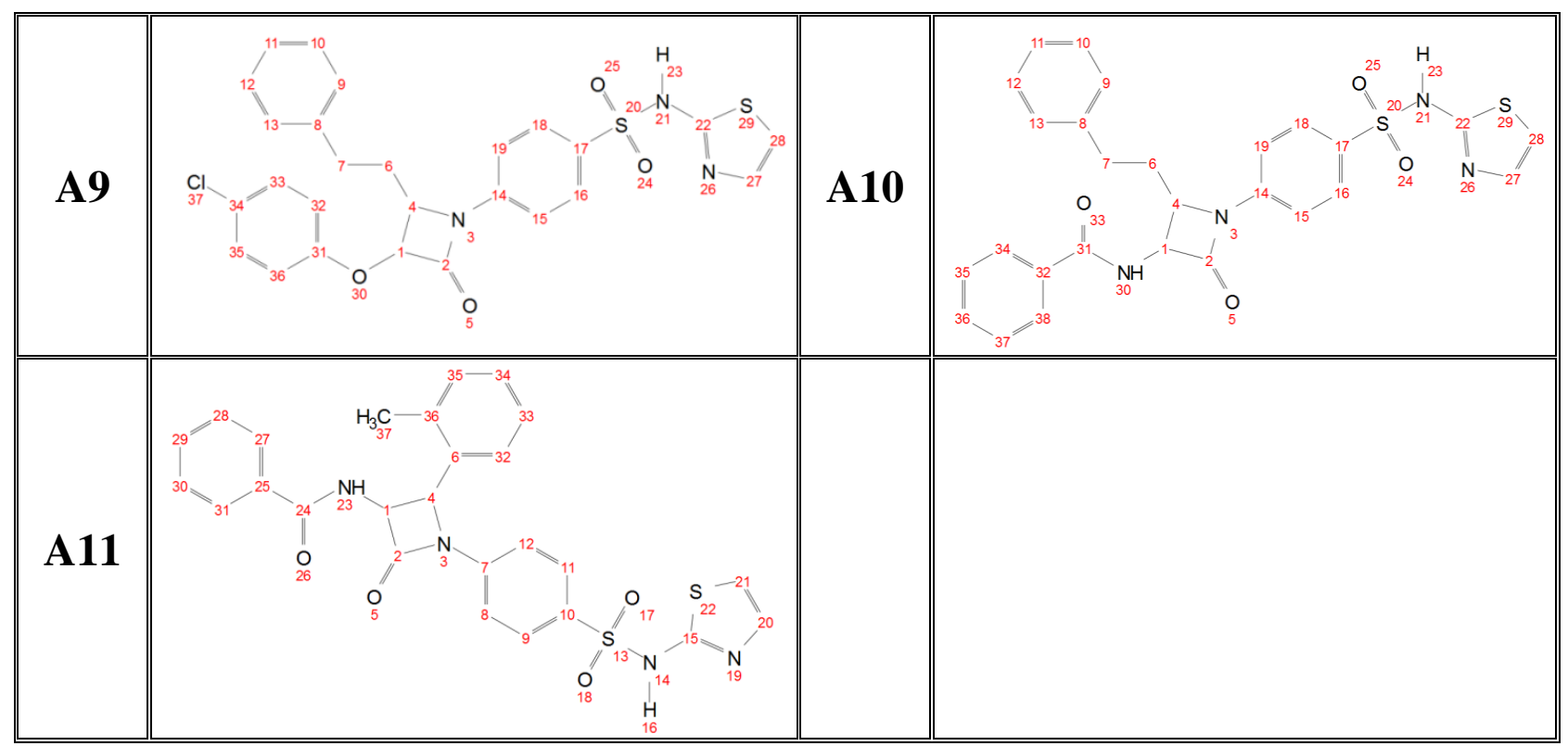

Compound A7: N-(2-oxo-1-(4-(N-(thiazol-2-yl)sulfamoyl)phenyl)-4-(o-tolyl) azetidin-3-yl)benzamide. The ${ }^{1} \mathrm{H}-\mathrm{NMR}$ of $\mathbf{A} 7(\boldsymbol{\delta}, \mathbf{p p m})$ (DMSO-d6) showed the chemical shift for the following protons: $12.62(\mathrm{~s}, 1 \mathrm{H}, \mathrm{N} 22), 7.92(\mathrm{~d}, 2 \mathrm{H}, \mathrm{C} 17$ \& 19), 7.62 (dd, 2H, C 16 \& 20), 7.18 (dd, 4H, C 8, 9, 11 \& 12), 6.95-6.98 (m, $5 \mathrm{H}, \mathrm{C} 31,32,34$ \& 35), 6.81 (d, 1H, C 28), 6.75 (d, 1H, C 29), 5.84 (d, 1H, C 1), $4.16(\mathrm{~d}, 1 \mathrm{H}, \mathrm{C} 4)$.. The ${ }^{13} \mathrm{C}-\mathrm{NMR}$ of $\mathrm{A} 7(\boldsymbol{\delta}, \mathbf{p p m})$ (DMSO-d6) reported the chemical shift for the following carbons: 167.69 (C23), 162.98 (C2), 156.03 (C7), 139.40 (C15), 134.32 (C14), 130.85 (C18), 129.87 (C9,11), 129.21 (C28), 129.11 (C17,19), $128.39 \quad$ (C32,34), $127.88 \quad$ (C33), $127.48 \quad$ (C10), $\delta 127.17$ (C31,35), 121.33 (C16,20), 118,62 (C8,12), 109.30 (C29), 74.15 (C1), 60.77 (C4).

Compound A8: 4-(3-(4-chlorophenoxy)-2-(4-chlorophenyl)-4-oxoazetidin-1-yl)N-(thiazol-2-yl) benzenesulfonamide The ${ }^{1} \mathbf{H}-\mathbf{N M R}$ of $\mathbf{A 8}(\boldsymbol{\delta}, \mathbf{p p m})$ (DMSO-d6) showed the chemical shift for the following protons: $12.71(\mathrm{~s}, 1 \mathrm{H}, \mathrm{N} 22), 7.69$ (d, 2H, C $17 \&$ 19), 7.53 (d, 2H, C 16 \& 20), 7.46 (d, 1H, C 28), 7.42 (d, 1H, C 29), 7.33 (d, 2H, C 31 \& 35), 7.25 (d, 2H, C 32 \& 34), 7.16 (d, 2H, C 9 \& 11), 6.96 (d, 2H, C 8 \& 12), 4.80 (d, 1H, C 1), 4.16 (d, 1H, C 4). The ${ }^{13}$ C-NMR of A 8 ( $\delta$, ppm) (DMSO-d6) reported the chemical shift for the following carbons: 167.69 (C23), 162.98 (C2), 156.03 (C7), 139.38 (C15), 134.70 (C33), 132.65 (C14), 130.85 (C18), 129.87 (C9,11), $129.21 \quad$ (C28), $129.11 \quad(\mathrm{C} 17,19), 128.52$ (C32,34), 128.51 (C31,35), 127.48 (C10), 121.33 (C16,20), 118.62 (C8,12), 109.30 (C29), 74.16 (C1), 60.44 (C4). 
Compound A9: 4-(3-(4-chlorophenoxy)-2-oxo-4-phenethylazetidin-1-yl)-N(thiazol-2-yl) benzenesulfonamide The ${ }^{1} \mathrm{H}-\mathrm{NMR}$ of $\mathrm{A9}(\boldsymbol{\delta}, \mathrm{ppm})$ (DMSO-d6) showed the chemical shift for the following protons: $12.64(\mathrm{~s}, 1 \mathrm{H}, \mathrm{N} 21), 8.11$ (dd, 2H, C 16 \& 18), 8.00 (dd, 2H, C 15 \& 19), 7.16 (m, 5H, C 9-13 aromatic), 7.02 (dd, 4H, C 32, 33, 35 \& 36), 6.85 (d, 1H, C 27), 6.81 (d, 1H, C 28), 4.80 (d, 1H, C1), 3.90 (d, 1H, C 4), 2.67 (t, 2H, C 7), 1.82 (t, 2H, C 6). The ${ }^{13}$ C-NMR of A9 ( $\delta$, ppm) (DMSO-d6) reported the chemical shift for the following carbons: 167.69 (C22), 165.79 (C2), 156.55 (C31), 143.14 (C8), 139.33 (C14), 130.90 (C17), 129.87 (C33,35), 129.21 (C27), 129.13 (C16,18), 128.74 (C9,13), 128.68 (C10,12), $127.48 \quad$ (C34), 126.57 (C11), 120.29 (C15,19), $118.63 \quad$ (C32,36), 109.30 (C28), 81.53 (C1), 59.33 (C4), 33.34 (C7), 27.56 (C6).

Compound A10: N-(2-oxo-4-phenethyl-1-(4-(N-(thiazol-2yl)sulfamoyl)phenyl)azetidin-3-yl)benzamide. The ${ }^{1} \mathbf{H}-\mathbf{N M R}$ of $\mathbf{A 1 0}(\boldsymbol{\delta}, \mathbf{p p m})$ (DMSO-d6) showed the chemical shift for the following protons: $10.75(\mathrm{~s}, 1 \mathrm{H}$, N 21), 8.41 (s, 1H, N 30), 7.98 (d, 2H, C 16 \& 18), 7.63 (d, 2H, C 15 \& 19), 7.42$7.52(\mathrm{~m}, 10 \mathrm{H}, \mathrm{C} 9,10,11,12,13,34,35,36,37 \& 38$ aromatic), $6.76(\mathrm{~d}, 1 \mathrm{H}, \mathrm{C}$ 27), 6.56 (d, 1H, C 28), 4.19 (d, 1H, C1), 3.91 (d, 1H, C 4), 3.15 (t, 2H, C 7), 2.94 $(\mathrm{t}, 2 \mathrm{H}, \mathrm{C} 6)$. The ${ }^{13} \mathrm{C}-\mathrm{NMR}$ of $\mathrm{A} \mathbf{1 0}(\boldsymbol{\delta}, \mathbf{p p m})$ (DMSO-d6) reported the chemical shift for the following carbons: 167.69 (C22), 166.60 (C31), 166.54 (C2), 143.06 (C8), 139.63 (C14), 134.63 (C32), 131.95 (C36), 130.90 (C17), 129.21 (C27), 129.13 (C16,18), 128.89 (C35,37), 128.74 (C9,13), 128.68 (C10,12), 127.30 (C34,38), 126.57 (C11), 120.26 (C15,19), 109.30 (C28), 59.06 (C1), 57.79 (C4), 33.24 (C7), 27.26 (C6).

Compound A11: N-(2-oxo-1-(4-(N-(thiazol-2-yl)sulfamoyl)phenyl)-4-(o-tolyl) azetidin-3-yl)benzamide. The ${ }^{1} \mathrm{H}-\mathrm{NMR}$ of $\mathrm{A10}(\boldsymbol{\delta}, \mathrm{ppm})$ (DMSO-d6) showed the chemical shift for the following protons: $10.85(\mathrm{~s}, 1 \mathrm{H}, \mathrm{N} \mathrm{14}), 8.56(\mathrm{~s}, 1 \mathrm{H}, \mathrm{C} \mathrm{23})$, 7.85 (d, 2H, C 27 \& 31), 7.84 (d, 2H, C 9 \& 11), 7.53 (s, 1H, C 29), 7.44 (m, 4H, C 8, 12, 28 \& 30), 7.18 (m, 4H, C 32, 33, 34 \& 35), 7.13 (d, 1H, C 20), 6.69 (d, 1H, C 21), 5.50 (d, 1H, C 1), 5.12 (d, 1H, C 4), 2.47 (s, 3H, C 37). The ${ }^{13}$ C-NMR of A $10(\delta, \mathrm{ppm})$ (DMSO-d6) reported the chemical shift for the following carbons: 167.69 (C15), 166.61 (C2), 166.36 (C24), 139.81 (C7), 137.61 (C36), 136.74 (C6), $\delta 134.55$ (C25), 131.95 (C29), 130.85 (C10), 129.35 (C35), 129.21 (C20), 129.10 (C9,11), 128.89 (C28,30), 127.31 (C34), 127.31 (C27,31), 126.99 (C32), 126.54 (C33), 121.39 (C8,12), 109.30 (C21), 59.65 (C4), 59.46 (C1), 19.40 (C37). 
Antimicrobial study: Determination of minimum inhibitory concentration (MIC):

After The detection of $\beta$ lactamases in bacterial isolates, a broth microdilution method was used to evaluate the (MIC), as a serial of 10 doubling dilution of the synthesized compounds and standard antibacterial
(Amoxiclav) (Amoxicillin 2000mg + clavulanic acid 400mg), Amoxicillin, Cefotaxime, Ceftriaxone, and Ciprofloxacin) was tested with final concentration starting from 2000 $\mathrm{mg} / \mathrm{ml}$ (and from $5000 \mathrm{mg} / \mathrm{ml}$ for Amoxicillin). The results were summarized in table (7).

Table (7): Minimum inhibition concentration (MIC) for the synthesized compounds and the antibacterial.

\begin{tabular}{|c|c|c|c|c|c|c|c|c|c|}
\hline \multirow{3}{*}{$\begin{array}{c}\text { Compounds } \\
\text { No. }\end{array}$} & \multicolumn{4}{|c|}{ MIC $(\mu \mathrm{g} / \mathrm{ml})$} & \multirow{3}{*}{$\begin{array}{c}\text { Compounds } \\
\text { No. }\end{array}$} & \multicolumn{4}{|c|}{ MIC $(\mu \mathrm{g} / \mathrm{ml})$} \\
\hline & \multirow{2}{*}{$\begin{array}{c}\text { Gram(+)ve } \\
\begin{array}{c}\text { Staph. } \\
\text { aueus }\end{array}\end{array}$} & \multicolumn{3}{|c|}{ Gram (-) ve } & & \multirow{2}{*}{$\begin{array}{c}\text { Gram(+)ve } \\
\begin{array}{c}\text { Staph. } \\
\text { aureus }\end{array}\end{array}$} & \multicolumn{3}{|c|}{ Gram (-) ve } \\
\hline & & E. coli & $\begin{array}{c}K . \\
\text { pneumonia }\end{array}$ & $\begin{array}{c}. \\
\text { aeroginosa }\end{array}$ & & & E. coli & $\begin{array}{c}\text { K. } \\
\text { pneumonia }\end{array}$ & $\begin{array}{c}P . \\
\text { aeroginosa }\end{array}$ \\
\hline Amoxiclav & 1000 & 2000 & 2000 & 2000 & A7 & $>>2000$ & $>2000$ & $>2000$ & $>2000$ \\
\hline Amoxicillin & 2000 & 4000 & 4000 & 4000 & A8 & 2000 & 2000 & 2000 & $>2000$ \\
\hline Cefotaxime & $\begin{array}{c}7.8 \\
\end{array}$ & 125 & 3.9 & 3.9 & A9 & $>2000$ & $>2000$ & $>2000$ & $>2000$ \\
\hline Ceftriaxone & 31.25 & 125 & 3.9 & 7.8 & בA10 & $>>2000$ & $>>2000$ & 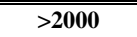 & $\overline{2>2000}$ \\
\hline Ciprofloxacin & < $<7.812$ & < < 7.812 & < < 7.812 & < < 7.812 & A11 & $>>2000$ & $>2000$ & $>>2000$ & $>>2000$ \\
\hline
\end{tabular}

Compounds A8 had an antibacterial activity and has $\mathrm{Cl}$ group which may be responsible for its antibacterial activity ${ }^{21}$.

\section{Determination of anti $\beta$-lactamase activities:}

Firstly amoxicillin and amoxiclav (2000/400mg) were incubated with the bacterial isolates by using three concentrations 3000 , 2000, and $1000 \mu \mathrm{g} / \mathrm{ml}$, the results would be conceders as a control for the results of the incubation of the synthesized compounds table (8).

Table (8): Inhibition zones for Amoxiclave and Amoxicillin against Gram(+)ve and Gram()ve bacteria.

\begin{tabular}{|c|c|c|c|c|c|c|c|c|c|c|c|c|}
\hline \multirow{4}{*}{$\begin{array}{c}\text { Compounds } \\
\text { No. }\end{array}$} & \multicolumn{12}{|c|}{ Inhibition zone diameter (mm) } \\
\hline & \multirow{2}{*}{\multicolumn{3}{|c|}{$\begin{array}{c}\text { Gram(+)ve } \\
\text { Staph. Aueus }\end{array}$}} & \multicolumn{9}{|c|}{ Gram (-) ve } \\
\hline & & & & \multicolumn{3}{|c|}{ E. coli } & \multicolumn{3}{|c|}{ K. pneumonia } & \multicolumn{3}{|c|}{ P. aeroginosa } \\
\hline & $\begin{array}{c}3000 \mu \mathrm{g} / \\
\mathrm{ml}\end{array}$ & 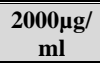 & $\begin{array}{c}1000 \mu \mathrm{g} / \\
\mathrm{ml}\end{array}$ & $\begin{array}{c}3000 \mu \mathrm{g} / \\
\mathrm{ml}\end{array}$ & $\begin{array}{c}2000 \mu \mathrm{g} / \\
\mathrm{ml}\end{array}$ & $\begin{array}{c}1000 \mu \mathrm{g} / \\
\mathrm{ml} 2\end{array}$ & $\begin{array}{c}3000 \mu \mathrm{g} / \\
\mathrm{ml}\end{array}$ & $\begin{array}{c}2000 \mu \mathrm{g} / \\
\mathrm{ml}\end{array}$ & $\begin{array}{c}1000 \mu \mathrm{g} / \\
\mathrm{ml}\end{array}$ & $\begin{array}{c}3000 \mu \mathrm{g} / \\
\mathrm{ml}\end{array}$ & $\begin{array}{c}2000 \mu \mathrm{g} / \\
\mathrm{ml}\end{array}$ & $\begin{array}{c}1000 \mu \mathrm{g} \\
\mathrm{ml}\end{array}$ \\
\hline Amoxiclave & 34 & 30 & 28 & 23 & 20 & 12 & 22 & 15 & 6 & 22 & 16 & 5 \\
\hline Amoxicillin & 33 & 30 & 27 & $\mathbf{0}$ & $\mathbf{0}$ & $\overline{0}$ & $\overline{0}$ & $\overline{0}$ & $\overline{0}$ & $\mathbf{0}$ & $\overline{0}$ & $\mathbf{0}$ \\
\hline
\end{tabular}

Amoxicillin shows antibacterial activity against Staph. Aureus only with no activity against Gram (-)ve strains. Amoxiclav on the other hand shows the same amoxicillin activity against Staph. Aureus, but also show 
activity against Gram (-)ve bacterial strains.

Depending on the above results, amoxicillin was used in two concentrations in the next step, $1000 \mu \mathrm{g} / \mathrm{ml}$ for Gram (+)ve bacteria and $2000 \mu \mathrm{g} / \mathrm{ml}$ for Gram (-)ve bacteria Table (9).

Table (9): Inhibition zones for the synthesized compounds as co-inhibitors with Amoxicillin against Gram-positive and Gram-negative pathogenic bacteria.

\begin{tabular}{|c|c|c|c|c|c|c|c|c|c|c|c|c|c|c|c|c|c|}
\hline \multirow{4}{*}{$\begin{array}{l}\text { Com. } \\
\text { No. }\end{array}$} & \multicolumn{8}{|c|}{ Inhibition zone diameter (mm) } & \multirow{4}{*}{$\begin{array}{l}\text { Com. } \\
\text { No. }\end{array}$} & \multicolumn{8}{|c|}{ Inhibition zone diameter (mm) } \\
\hline & \multirow{2}{*}{\multicolumn{2}{|c|}{$\begin{array}{l}\text { Gram(+)ve } \\
\text { Staph. aueus }\end{array}$}} & \multicolumn{6}{|c|}{$\begin{array}{ll}\text { Gram (-)ive } \\
\end{array}$} & & \multirow{2}{*}{\multicolumn{2}{|c|}{$\begin{array}{l}\text { Gram(+)ve } \\
\text { Staph. aueus }\end{array}$}} & \multicolumn{6}{|c|}{ Gram (-)ive } \\
\hline & & & \multicolumn{2}{|c|}{ E. coli } & \multicolumn{2}{|c|}{ K. pneumonia } & \multicolumn{2}{|c|}{ P. aeroginosa } & & & & \multicolumn{2}{|c|}{ E. coli } & \multicolumn{2}{|c|}{ K. pneumonia } & \multicolumn{2}{|c|}{$\begin{array}{c}P . \\
\text { aeroginosa }\end{array}$} \\
\hline & $1: 1$ & $1: 2$ & $1: 1 / 2$ & $1: 1$ & $1: 1 / 2$ & $1: 1$ & $1: 1 / 2$ & $1: 1$ & & $1: 1$ & $1: 2$ & $1: 1 / 2$ & $1: 1$ & $1: 1 / 2$ & $1: 1$ & $1: 1 / 2$ & $1: 1$ \\
\hline A7 & 28 & 30 & 25 & 28 & $\mathbf{0}$ & $\mathbf{0}$ & 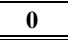 & $\mathbf{0}$ & A10 & 28 & 30 & $\mathbf{0}$ & $\mathbf{0}$ & $\mathbf{0}$ & $\mathbf{0}$ & $\mathbf{0}$ & $\mathbf{0}$ \\
\hline A8 & 28 & 30 & $\mathbf{0}$ & $\mathbf{0}$ & $\mathbf{0}$ & $\mathbf{0}$ & 0 & $\mathbf{0}$ & A11 & 28 & 30 & 28 & 30 & $\mathbf{0}$ & $\mathbf{0}$ & $\mathbf{0}$ & $\mathbf{0}$ \\
\hline A9 & 28 & 30 & $\mathbf{0}$ & $\mathbf{0}$ & $\mathbf{0}$ & $\mathbf{0}$ & $\mathbf{0}$ & $\mathbf{0}$ & & & & & & & & & \\
\hline
\end{tabular}

$1: 1=1000 \mu \mathrm{g} / \mathrm{ml}$ Amoxicillin : $1000 \mu \mathrm{g} / \mathrm{ml}$ synthesized compound for Gram(+)ve bacteria

$1: 2=1000 \mu \mathrm{g} / \mathrm{ml}$ Amoxicillin : $2000 \mu \mathrm{g} / \mathrm{ml}$ synthesized compound for Gram(+)ve bacteria

$1: 1 / 2=2000 \mu \mathrm{g} / \mathrm{ml}$ Amoxicillin : $1000 \mu \mathrm{g} / \mathrm{ml}$ synthesized compound for Gram(-)ve bacteria

$1: 1=2000 \mu \mathrm{g} / \mathrm{ml}$ Amoxicillin : $2000 \mu \mathrm{g} / \mathrm{ml}$ synthesized compound for Gram(-)ve bacteria

In general, the results indicated that all the synthesized compounds had no activity as anti $\beta$-lactamase Concerning the anti $\beta$ lactamase activities against $E$. coli bacteria, 2 compounds which are A7, and A11 showed strong anti $\beta$ lactamase activities resembling that of clavulanic acid, although both of them have no antibacterial activities. These compounds having one or more

\section{Conclusion:}

It was concluded that the $\beta$ lactamase TEM-1 active pocket prefers hydrophobic substituents, as the 2 synthesized active anti $\beta$ lactamase compounds having against Staph. aureus, K. pneumonia, and $P$. aeroginosa.

hydrophobic residue in its structure, this is coming true with the docking results which indicate that the selectivity for the $\beta$-lactamase enzyme increases as the compounds became more hydrophobic, as the active binding site pocket of the $\beta$-lactamase are mostly hydrophobic in nature ${ }^{22}$.

hydrophobic residue. So that the selectivity for the $\beta$-lactamase enzyme increases as the compounds became more hydrophobic, and the $\mathrm{Cl}$ group will increase the antibacterial activity of the synthesized compounds. 


\section{Acknowledgments:}

Our thanks to the Department of

Pharmaceutical Chemistry, College of

\section{References:}

1. Olsen, O. (2015). New promising b-lactamase inhibitors for clinical use. Eur. J. Clin. Microbiol. Infect Dis. 34, 1303-1308.

2. King, D.T., Sobhanifar, S., and Strynadka, N.C.J. (2016). One ring to rule them all: current trends in combating bacterial resistance to the b-lactams. Protein Sci. 25, 787-803.

3. McKenna, M. (2013). The last resort. Nature 499, 394-396.

4. Y. Sakurai, Y. Yoshida, K. Saitoh, M. Nemoto, A. Yamaguchi, T. Sawai, J Antibiot (Tokyo). (1990) 43, 403-410.

5. Araoka, H., Baba, M., Tateda, K., Ishii, Y., Oguri, T., Okuzumi, K., Oishi, T., Mori, S., Mitsuda, T., Moriya, K., et al. (2012). Monobactam and aminoglycoside combination therapy against metallo-b-lactamase-producing multidrug resistant Pseudomonas aeruginosa screened using a 'break-point checkerboard plate'. Jpn. J. Infect. Dis. 65, 84-87.

6. Rongfeng Li, Ryan A. O., and Craig A. T., 2016. Identification
Pharmacy, University of the Mosul for their support.

and Characterization of the Sulfazecin Monobactam

Biosynthetic Gene Cluster. Cell Chemical Biology (2016), http://dx.doi.org/10.1016/j.chembi ol.2016.11.010.

7. Alwan S. M.. (2016). Computational Calculations of Molecular Properties and Molecular Docking of New and Reference Cephalosporins on Penicillin Binding Proteins and Various $\beta$-Lactamases. Journal of Pharmacy and Pharmacology 4: 212-225.

8. Rafiq1 Z., Saranya S. and Vaidyanathan R.. (2018). Computational Docking And In Silico Analysis Of Potential Efflux Pump Inhibitor Punigratane. International Journal Of Pharmacy And Pharmaceutical Sciences Vol 10, Issue 3.

9. Settypalli T., V. R. Chunduri, A. K. Maddineni, N. Begari, R. Allagadda, P. Kotha and A. R. Chippada.( 2019). Design, Synthesis, in silico docking studies and biological evaluation of novel quinoxaline-hydrazide hydrazone- 
1,2,3-triazole hybrids as $\alpha$ glucosidase inhibitors, antioxidants. New J. Chem.DOI: 10.1039/C9NJ02580D.

10.Kahlan M. A. Al-Shammary,. (2012). Synthesis of Some Schiff's Bases Containing 1,3,4Thiadiazole Ring and Their Properties as Antioxidants. Journal of Al-Nahrain University.15 (3):49-54.

11.Nadjet R., Amjad, M. Al-Yahyawi, Sanaa, K. Bardaweel, et al. (2015).Synthesis of Novel 2,5Disubstituted-1,3,4-thiadiazoles

Clubbed 1,2,4-Triazole, 1,3,4Thiadiazole, 1,3,4-Oxadiazole and/or Schiff's Base as Potential Antimicrobial and Antiproliferative Agents.

Molecules. 20: 16048-16067.

12.Medvedeva A. S., Andreev M. V., Safronova L. P. and Afonin A. V. Afonin.(2005). Synthesis of Trimethylsilylpropynoyl Chloride. Russian Journal of Organic Chemistry, Vol. 41, No. 10, 2005, pp. 1463-1466.

13.Arun K., Lalit Sharma, and Monika Kaura. (2013). Synthesis And Comparative Antimicrobial Study Of Beta-Lactam Derivatives. International Journal Of Pharmaceutical And Chemical
Sciences Issn: 2277:5005, Vol. 2 (2) Apr-Jun

14.Livermore D. M. and Brown D. F. J..(2005). Detection of $\beta$ lactamase-mediated resistance. AL-Qadisiyah Journal of pure Science Vol. 23 No. 2

15.Al-Kudheiri M. K., Al-Mohana A. M. and Hussein A. N.(2014). Detection of $\beta$-lactamases producing Methicillin-Resistant Staphylococcus aureus (MRSA). Open Journal of Clinical Diagnostics, 4, 47-52

16.Pitucha M., Wos M., MiazgaKarska M., Klimek K., and Mirosław B.. (2016). Synthesis, antibacterial, and antiproliferative potential of some new 1pyridinecarbonyl-4-substituted thiosemicarbazide derivatives. Med Chem Res 25:1666-1677

17.Ashraf Z., Bais A., Manir Md. M. and Niazi U..(2015). Novel Penicillin Analogues as Potential Antimicrobial Agents; Design, Synthesis, and Docking Studies. Pone Journal. https: //doi.org/ 10.1371/ journal.pone.0135293

18.Tondi D., Morandi F., Bonnet R., Costi M. P., and Shoichet B. K. (2005).

Structure-Based Optimization of a Non- $\beta$-lactam Lead Results in Inhibitors That Do Not Up-Regulate $\beta$-Lactamase 
Expression in Cell Culture. J Am Chem Soc. April 6; 127(13): 4632-4639.

19.Avci F. G., Altinisik F. E., Karacan I., Karagoz D. S., Ersahin S., Eren A., Sayar N. A., Ulu D.V., Olmez E. O., Akbulut B. S..(2018). Targeting a hidden site on class A beta-lactamases. Journal of Molecular Graphics and Modelling 10.1016/ j.jmgm. 2018.06.007

20.Myers A. G., Seiple 1. B., Sussman R. J.(2016). Monobactams and methods of their synthesis and use. The United States Patent Application Publication Pub. No.: US 2016/0326157, A1US 2016.0326157A1

21.Chawla P., Singh R., Saraf S. K.(2012). Effect of chloro and fluoro groups on the antimicrobial activity of 2,5-disubstituted 4thiazolidinones: a comparative study. Med Chem Res, 21(10):3263-3271, DOI 10.1007/s00044-011-9864-1

22.Avci F.G., Altinisik F.E., Vardar Ulu D., Ozkirimli O. E., Akbulut B. S..(2016). An evolutionarily conserved allosteric site modulates beta-lactamase activity, J. Enzyme Inhib. Med. Chem. 31, 33-40. DOI:10.1080/14756366.2016.1201 813. 